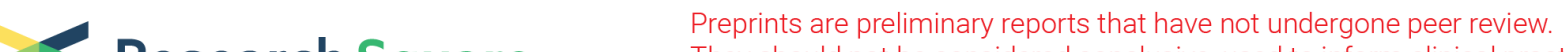 $\begin{array}{ll}\text { Research Square } & \begin{array}{l}\text { They should not be considered conclusive, used to inform clinical practice, } \\ \text { or referenced by the media as validated information. }\end{array}\end{array}$ \\ The Effects of Physical Activity on Mental Health During the COVID-19 Pandemic: a Systematic Review
}

Priscila Marconcin ( $\square$ priscilamarconcin@fmh.ulisboa.pt)

Universidade de Lisboa

\section{André 0. Werneck}

Center for Epidemiological Research in Nutrition and Health, Department of Nutrition, School of Public Health, São Paulo, Brazil.

\section{Miguel Peralta}

CIPER, Universidade de Lisboa

Andreas Ihle

University of Geneva

\section{Élvio Gouveia}

Universidade da Madeira

\section{Gerson Ferrari}

Universidad de Santiago de Chile (USACH)

\section{Hugo Sarmento}

University of Coimbra, Research Unit for Sport and Physical Activity (CIDAF). Faculty of Sport Sciences and Physical Education, Coimbra, Portugal

\section{Adilson Marques}

Universidade de Lisboa

\section{Research Article}

Keywords: pandemic, SARS CoV-2, exercise, mental health, anxiety

Posted Date: November 10th, 2021

DOI: https://doi.org/10.21203/rs.3.rs-1026835/v1

License: (c) (1) This work is licensed under a Creative Commons Attribution 4.0 International License.

Read Full License 


\section{Abstract}

Introduction: Coronavirus disease-19 (COVID-19) pandemic affected countries worldwide and has changed peoples' lives. A reduction in physical activity and an increase in mental health problems were observed. Thus, this systematic review aims to examine the association between physical activity and mental health during the COVID-19 pandemic.

Methods: In January 2021, a search was applied to PubMed, Scopus, and Web of Science. Eligibility criteria included cross-sectional, prospective, longitudinal study design and studies published in English; outcomes included physical activity and mental health (e.g., depressive symptoms, anxiety, positive and negative effects, well-being).

Results: Nineteen studies were included in this review. Overall, the studies suggested that higher physical activity is associated with higher well-being, quality of life as well as lower depressive symptoms, anxiety, and stress, independently of age. There was no consensus for the optimal physical activity level for mitigating negative mental symptoms, neither for the frequency nor for the type of physical activity. Women were more vulnerable to mental health changes and men were more susceptive to physical activity changes.

Conclusion: Physical activity seems to be a good and effective choice to mitigate the negative effects of the COVID-19 pandemic on mental health. Public health policies should alert for alternatives to increment physical activity during the stay-at-home orders in many countries.

\section{Background}

The severe acute respiratory syndrome coronavirus-2 (SARS-CoV-2) is a highly contagious virus that infects humans and causes coronavirus disease-19 (COVID-19), which is currently having a damaging impact on almost all countries in the world (1). To bring this pandemic to an end, a large share of the world needs to be immune to the virus, and the safest way to achieve this is with a vaccine. Fortunately, in December 2020 the vaccination started in the United Kingdom (2) and is currently pursued in different countries (3). However, the number of infected people and deaths continues to grow (4). Therefore, from the beginning of the pandemic to the present day, as a community mitigation strategy used to reduce the spread of COVID-19, most countries adopted the stay-at-home order as well as the stimulation of facemask wearing and hygiene habits $(5,6)$.

As a consequence of the stay-at-home strategies, studies had reported multiple behaviour changes. Some common impacts include disturbed eating behaviours (7), changes in alcohol consumption (8), and substance use (9). A wide range of psychological outcomes has been observed during the virus outbreak, including a reduction in well-being as well as increases in depressive and anxiety symptoms $(10,11)$. Considering the need for social distancing measures, the investigation of possible factors that can mitigate the negative effect of social distancing on mental health should help the promotion of intervention strategies. 
Physical activity (PA) is well recognised as a key factor for the prevention and management of mental illbeing, including mental disorders such as depression and anxiety as well as positive mental health as well-being $(12,13)$. Nevertheless, globally, approximately $23 \%$ of adults and $81 \%$ of adolescents do not meet the World Health Organisation (WHO) global recommendations on PA for health (14-16). This situation worsened with the COVID-19 pandemic. Studies have demonstrated that PA declined and sedentary behaviour increased during the COVID-19 pandemic stay at home order, regardless of the subpopulation (17). Different studies sought to investigate whether these changes in PA were associated with mental health indicators during the covid-19 pandemic and a previous systematic review synthetised that PA is an effective strategy to face the COVID-19 pandemic psychological effect (18). However, the previous review included articles published between 1 January 2019, and 15 July 2020, before the second wave of the covid-19 pandemic. Therefore, this systematic review aimed to update those findings and clarify if PA is associated with mental health during the COVID-19 pandemic and to analyse if PA mitigates the effects of the stay-at-home order on mental health.

\section{Methods}

\section{Design}

This systematic review focuses on peer-reviewed journal articles about the association of PA on mental health during the COVID-19 pandemic that were published until 30 January 2021.

\section{Data Sources and Searches}

A systematic review protocol was registered with the PROSPERO database on the $29^{\text {th }}$ of January 2021 (IDCRD42021233921). Searches were then conducted on the next day, in PubMed, Scopus, and Web of Science. The search was performed in the three databases using the terms: physical activity OR physical inactivity OR exercise OR training OR sport* OR fitness OR physical function* AND mental health OR psychological health OR depress* OR anxiety OR psychological function* OR mental function* AND coronavirus disease OR COVID-19 OR SARS-CoV-2 OR lockdown OR shutdown OR quarantine OR confinement OR social isolation.

\section{Study Selection}

Observational studies (cross-sectional, prospective, or longitudinal) were eligible for this review. Furthermore, studies were also required to meet the following criteria: (1) assessing PA by a validated instrument, (2) assessing mental health by a validated instrument, (3) presenting an association analysis of PA and mental health. Studies with sample characteristics as pregnant women, chronic disease patients, athletes, covid-19 survivors, frail older adults, were excluded. Besides, studies that reported PA as a moderate or mediated variable were also excluded. Two co-authors screened titles and abstracts to identify articles that met the inclusion criteria. Two co-authors read the articles and decided whether they should be included in the analysis or excluded. The inclusion decision was consensual and in cases of disagreement, the decision was made by mutual agreement. 


\section{Data Extraction and Synthesis of Results}

Data extraction was completed independently by one co-author. Data extracted from all studies included study details (author, year of publication, study design, recruitment processes, and date and location of study); participant characteristics (sex, mean age); outcome and instruments, and main findings. A table was made for articles that analysed the association of PA on mental health among adults, and another table for the analyses of the association of PA on mental health among children and adolescents.

\section{Quality assessment}

The risk of bias was assessed by two independent reviewers, using the Newcastle-Ottawa Scale (NOS) (19) which was also adapted for cross-sectional studies (20) Therefore, we used the original scale for cohort studies and the adapted scale for the cross-sectional studies. The original scale varies between 0 and 9 , while the adapted scale for cross-sectional studies varies between 0 and 10 , with higher scores indicating better quality research.

\section{Narrative synthesis}

Considering the heterogeneity of methods used for the estimation of the exposures and outcomes, it was not possible to conduct a meta-analysis. Therefore, we compared the findings across the included articles according to each outcome.

\section{Results}

\section{Results of the Search}

From the database search, 260 records were identified. After removing duplicates, the title and abstracts of 113 articles were screened concerning the eligibility criteria, and 56 were excluded primarily. The full texts of the remaining 57 articles were evaluated and 38 were excluded for the following reasons: sample characteristics $(n=12)$, data were not analysed regarding the association between PA and mental health variables $(n=7)$, review studies $(n=2)$, no valid instruments to assess PA $(n=14)$ and mental health $(n=2)$, the study was not in the period of the covid-19 pandemic $(n=1)$. Nineteen studies were included in this review, 16 about adults and old adults and 3 about children and adolescents. The flow diagram of study search and selection was created according to the Preferred Reporting Items for Systematic Reviews and Meta-Analyses (PRISMA) (21) and is presented in Figure 1. The mean score of quality was 5.0 \pm 1.7 . More details are presented in Table 1 and Table 2. 
Table 1

Characteristics and the main results of the association of physical activity/exercise on mental health among adults.

\begin{tabular}{|c|c|c|c|c|}
\hline Authors & $\begin{array}{l}\text { Study design, sample characteristics } \\
\text { (n, sex, age), recruitment, country }\end{array}$ & $\begin{array}{l}\text { Outcomes } \\
\text { (instruments) }\end{array}$ & $\begin{array}{l}\text { Study } \\
\text { quality* }\end{array}$ & Main findings \\
\hline $\begin{array}{l}\text { Chouchou } \\
\text { et al. } 2020\end{array}$ & $\begin{array}{l}\text { Cross-sectional, } 400 \text { participants } \\
\text { (58.2\% women, mean age } 29.8 \pm 11.5 \\
\text { years), recruitment by online survey } \\
\text { between the } 35 \text { th and } 54 \text { th days of } \\
\text { lockdown, Reunion Island. }\end{array}$ & $\begin{array}{l}\text { Subjective well- } \\
\text { being (WHO-5). } \\
\text { Sleep quality } \\
\text { (PSQI). } \\
\text { Physical activity } \\
\text { (IPAQ). }\end{array}$ & 6 & $\begin{array}{l}\text { Those } \\
\text { reporting the } \\
\text { highest } \\
\text { decrease in } \\
\text { well-being } \\
\text { (4th and 3th } \\
\text { quartiles) } \\
\text { also reported } \\
\text { the highest } \\
\text { decrease in } \\
\text { their total, } \\
\text { moderate and } \\
\text { intense } \\
\text { weekly PA. } \\
\text { Impairment in } \\
\text { well-being } \\
\text { was } \\
\text { independently } \\
\text { associated } \\
\text { with weekly } \\
\text { PA. }\end{array}$ \\
\hline $\begin{array}{l}\text { Coughenour } \\
\text { et al. } 2020\end{array}$ & $\begin{array}{l}\text { Cross-sectional, } 194 \text { universities } \\
\text { ( } 73 \% \text { women, mean age } 25.1 \pm 7.8 \\
\text { years), online survey between May } 7 \\
\text { and May 28, 2020, United States } \\
\text { (Southern Nevada). }\end{array}$ & $\begin{array}{l}\text { Estimated } \\
\text { cardiorespiratory } \\
\text { fitness } \\
\text { (algorithm } \\
\text { include age, } \\
\text { body } \\
\text { composition, } \\
\text { resting heart rate } \\
\text { and PA). } \\
\text { Depressive } \\
\text { symptoms } \\
\text { (PHQ-9). }\end{array}$ & 3 & $\begin{array}{l}\text { Significant } \\
\text { but small } \\
\text { correlation } \\
\text { between the } \\
\text { change in } \\
\text { weekly } \\
\text { physical } \\
\text { activity } \\
\text { minutes and } \\
\text { the change in } \\
\text { PHQ-9 scores. }\end{array}$ \\
\hline $\begin{array}{l}\text { Eric et al. } \\
(2020)\end{array}$ & $\begin{array}{l}\text { Cross-sectional, } 1,800 \text { adults }(42.7 \% \\
\text { women, } 50.7 \% \text { aged between } 21 \text { and } \\
35 \text { years) online survey, Nigeria. }\end{array}$ & $\begin{array}{l}\text { Subjective well- } \\
\text { being (WHO-5). } \\
\text { Physical activity } \\
\text { (EPQ). }\end{array}$ & 5 & $\begin{array}{l}\text { Total Daily } \\
\text { Energy } \\
\text { Expenditure } \\
\text { on exercise } \\
\text { during the } \\
\text { pandemic } \\
\text { was found to } \\
\text { be } \\
\text { significantly } \\
\text { related to } \\
\text { mental } \\
\text { wellbeing. }\end{array}$ \\
\hline
\end{tabular}




\begin{tabular}{|c|c|c|c|c|}
\hline Authors & $\begin{array}{l}\text { Study design, sample characteristics } \\
\text { (n, sex, age), recruitment, country }\end{array}$ & $\begin{array}{l}\text { Outcomes } \\
\text { (instruments) }\end{array}$ & $\begin{array}{l}\text { Study } \\
\text { quality* }\end{array}$ & Main findings \\
\hline $\begin{array}{l}\text { Faulkner et } \\
\text { al. } 2020\end{array}$ & $\begin{array}{l}\text { Cross-sectional, } 8,425 \text { participants } \\
\text { (70.7\% female; mean age } 44.5 \pm 14.8 \\
\text { years), online survey within the first } \\
2-6 \text { weeks of government-mandated } \\
\text { COVID- } 19 \text { restrictions, UK, Ireland, } \\
\text { New Zealand and Australia. }\end{array}$ & $\begin{array}{l}\text { Physical activity } \\
\text { (IPAQ). } \\
\text { Exercise } \\
\text { behaviour } \\
\text { change (Stages } \\
\text { of Change } \\
\text { scale). } \\
\text { Subjective well- } \\
\text { being (WHO-5). } \\
\text { Depressive, } \\
\text { anxiety and } \\
\text { stress } \\
\text { symptoms } \\
\text { (DASS-9). }\end{array}$ & 7 & $\begin{array}{l}\text { Moderate } \\
\text { positive } \\
\text { correlations } \\
\text { between PA } \\
\text { and WHO-5 } \\
\text { scores and } \\
\text { negative } \\
\text { correlations } \\
\text { between PA } \\
\text { and } \\
\text { depressive, } \\
\text { anxiety and } \\
\text { stress } \\
\text { symptoms } \\
\text { during the } \\
\text { initial COVID- } \\
19 \\
\text { restrictions. }\end{array}$ \\
\hline $\begin{array}{l}\text { Lesser and } \\
\text { Nienhuis, } \\
\text { (2020) }\end{array}$ & $\begin{array}{l}\text { Cross-sectional, } 1,098 \text { participants } \\
\text { ( } 79.3 \% \text { women, mean age } 42 \pm 15 \\
\text { years) online survey during April and } \\
\text { early May } 2020 \text {, Canada }\end{array}$ & $\begin{array}{l}\text { Physical activity } \\
\text { (GLQ). } \\
\text { Motivation to } \\
\text { exercise (BREQ- } \\
\text { 3). } \\
\text { Anxiety (GAD-7). } \\
\text { Overall well- } \\
\text { being (MHC-SF). }\end{array}$ & 4 & $\begin{array}{l}\text { Inactive } \\
\text { participants } \\
\text { scored } \\
\text { significantly } \\
\text { lower on the } \\
\text { mental health } \\
\text { continuum } \\
\text { than active } \\
\text { participants, } \\
\text { though was a } \\
\text { non- } \\
\text { significant } \\
\text { difference in } \\
\text { generalized } \\
\text { anxiety. }\end{array}$ \\
\hline $\begin{array}{l}\text { Lin et al. } \\
(2020)\end{array}$ & $\begin{array}{l}\text { Cross-sectional, } 628 \text { healthy college } \\
\text { students ( } 64.8 \% \text { female, mean aged } \\
20.18 \pm 1.8 \text { years), online survey, } \\
\text { China. }\end{array}$ & $\begin{array}{l}\text { Depression } \\
\text { (CES-D). } \\
\text { Physical activity } \\
\text { (IPAQ-SF). }\end{array}$ & 6 & $\begin{array}{l}\text { Depression } \\
\text { negatively } \\
\text { correlated } \\
\text { with MET- } \\
\text { minutes/week } \\
\text { in moderate- } \\
\text { intensity PA } \\
\text { but not } \\
\text { vigorous and } \\
\text { walking } \\
\text { scores. }\end{array}$ \\
\hline
\end{tabular}




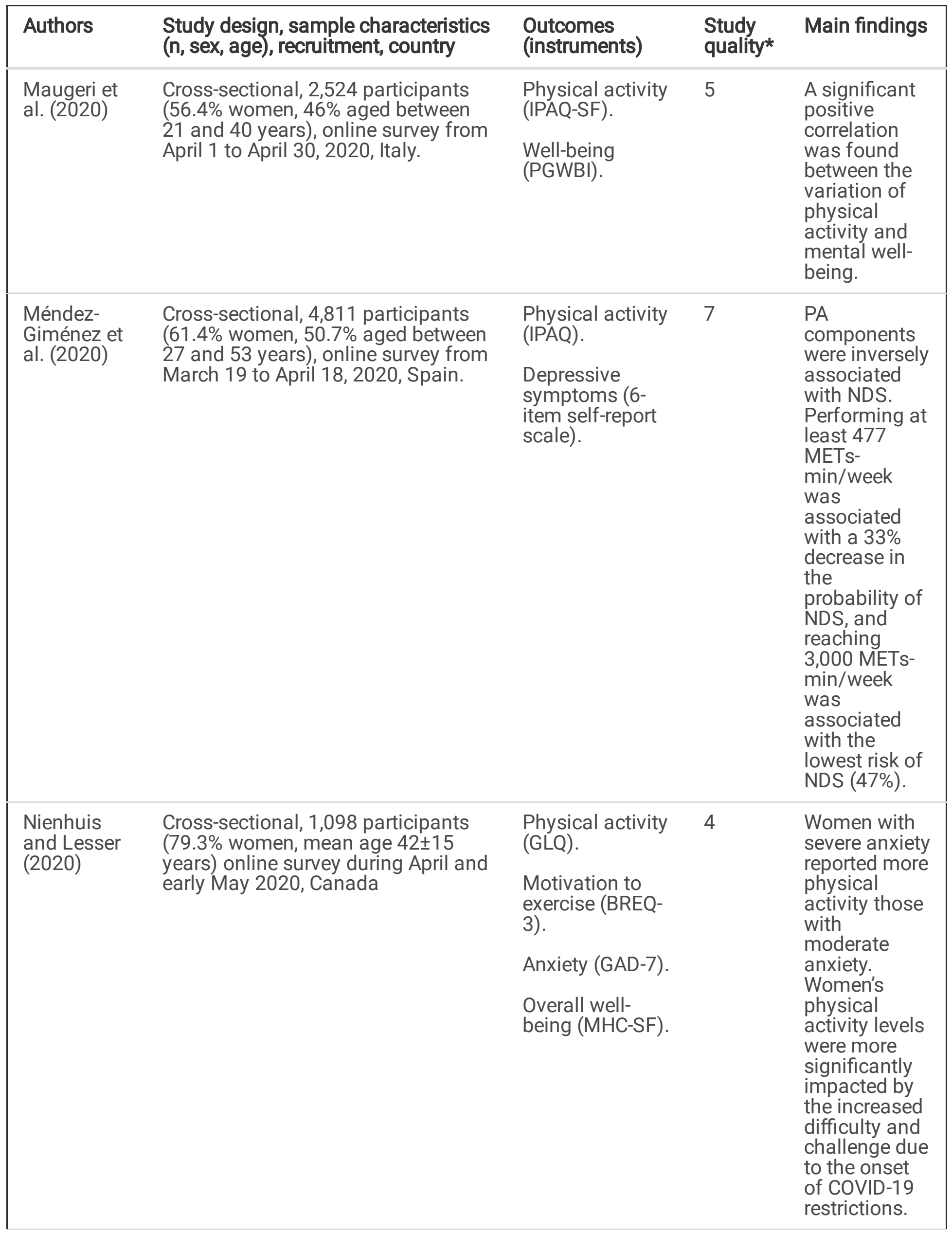




\begin{tabular}{|c|c|c|c|c|}
\hline Authors & $\begin{array}{l}\text { Study design, sample characteristics } \\
\text { (n, sex, age), recruitment, country }\end{array}$ & $\begin{array}{l}\text { Outcomes } \\
\text { (instruments) }\end{array}$ & $\begin{array}{l}\text { Study } \\
\text { quality* }\end{array}$ & Main findings \\
\hline $\begin{array}{l}\text { Ozdemir et } \\
\text { al. (2020) }\end{array}$ & $\begin{array}{l}\text { Cross-sectional, } 2,301 \text { participants } \\
(61.1 \% \text { women, mean age } 36.2 \pm \\
10.9) \text {, online survey started eight } \\
\text { weeks after the first case of COVID- } \\
19 \text { was officially reported, Turkey. }\end{array}$ & $\begin{array}{l}\text { Physical activity } \\
\text { (IPAQ). } \\
\text { Depression } \\
\text { (BDI). } \\
\text { Anxiety } \\
\text { symptoms (BAI). } \\
\text { Quality of life } \\
\text { (WHOQOL-BREF } \\
\text { TR). }\end{array}$ & 8 & $\begin{array}{l}\text { Weak positive } \\
\text { relationship } \\
\text { between } \\
\text { physical } \\
\text { activity levels } \\
\text { and quality of } \\
\text { life, while } \\
\text { there was a } \\
\text { weak } \\
\text { negative } \\
\text { relationship } \\
\text { between } \\
\text { physical } \\
\text { activity levels, } \\
\text { depression } \\
\text { and anxiety. }\end{array}$ \\
\hline $\begin{array}{l}\text { Savage et } \\
\text { al. (2020) }\end{array}$ & $\begin{array}{l}\text { Longitudinal cohort study, } 214 \\
\text { students ( } 72 \% \text { women, mean age } 20 \\
\text { years), online survey on the first } \\
\text { week of 'lockdown' } 20 \text { March } 2020 \\
\text { and during the fifth week of } \\
\text { lockdown } 27 \text { April 2020, UK. }\end{array}$ & $\begin{array}{l}\text { Physical activity } \\
\text { (EVS). } \\
\text { Mental well- } \\
\text { being } \\
\text { (WEMWBS). }\end{array}$ & 2 & $\begin{array}{l}\text { Positive } \\
\text { association } \\
\text { was found } \\
\text { between } \\
\text { perceived } \\
\text { stress and } \\
\text { sedentary } \\
\text { behaviour. }\end{array}$ \\
\hline $\begin{array}{l}\text { Stanton et } \\
\text { al. }(2020)\end{array}$ & $\begin{array}{l}\text { Cross-sectional, } 1,491 \text { adults ( } 67 \% \\
\text { women, mean age } 50.5 \pm 14.9 \text { years), } \\
\text { online survey during April } 2020, \\
\text { Australia. }\end{array}$ & $\begin{array}{l}\text { Physical activity } \\
\text { (AAS). } \\
\text { Depressive and } \\
\text { anxiety } \\
\text { symptoms } \\
\text { (DASS21). }\end{array}$ & 6 & $\begin{array}{l}\text { Negative } \\
\text { changes in } \\
\text { physical } \\
\text { activity were } \\
\text { associated } \\
\text { with higher } \\
\text { depressive } \\
\text { and anxiety } \\
\text { symptoms. }\end{array}$ \\
\hline
\end{tabular}




\begin{tabular}{|c|c|c|c|c|}
\hline Authors & $\begin{array}{l}\text { Study design, sample characteristics } \\
\text { (n, sex, age), recruitment, country }\end{array}$ & $\begin{array}{l}\text { Outcomes } \\
\text { (instruments) }\end{array}$ & $\begin{array}{l}\text { Study } \\
\text { quality* }\end{array}$ & Main findings \\
\hline $\begin{array}{l}\text { Xiang et al. } \\
(2020)\end{array}$ & $\begin{array}{l}\text { Cross-sectional, } 1,396 \text { college } \\
\text { students }(36.9 \% \text { women, mean age } \\
20.68 \pm 1.84) \text {, online survey, China. }\end{array}$ & $\begin{array}{l}\text { Anxiety and } \\
\text { depressive } \\
\text { symptoms (SAS } \\
\text { and SDS). } \\
\text { Physical activity } \\
\text { (IPAQ). }\end{array}$ & 6 & $\begin{array}{l}\text { A high level of } \\
\text { physical } \\
\text { activity was } \\
\text { significantly } \\
\text { closely } \\
\text { associated } \\
\text { with low } \\
\text { anxiety, while } \\
\text { a moderate or } \\
\text { high level of } \\
\text { physical } \\
\text { activity was } \\
\text { significantly } \\
\text { associated } \\
\text { with reduced } \\
\text { depression } \\
\text { after } \\
\text { adjusting } \\
\text { confounding } \\
\text { demographic } \\
\text { factors. }\end{array}$ \\
\hline $\begin{array}{l}\text { Zhang et al. } \\
(2020)\end{array}$ & $\begin{array}{l}\text { Longitudinal survey, } 66 \text { participants } \\
(62.12 \% \text { women, mean age } \\
20.70 \pm 2.11) \text {, online survey February } \\
19 \text {, on March } 5 \text { and on March } 20 \text {, } \\
\text { China. }\end{array}$ & $\begin{array}{l}\text { Physical activity } \\
\text { (IPAQ). } \\
\text { Depressive, } \\
\text { anxiety and } \\
\text { stress } \\
\text { symptoms } \\
\text { (DASS21). }\end{array}$ & 3 & $\begin{array}{l}\text { Physical } \\
\text { activity } \\
\text { directly } \\
\text { alleviated } \\
\text { general } \\
\text { negative } \\
\text { emotions and } \\
\text { the maximal } \\
\text { mitigation } \\
\text { effect } \\
\text { occurred } \\
\text { when weekly } \\
\text { physical } \\
\text { activity was } \\
\text { about } 2500 \\
\text { METs. }\end{array}$ \\
\hline
\end{tabular}




\begin{tabular}{|c|c|c|c|c|}
\hline Authors & $\begin{array}{l}\text { Study design, sample characteristics } \\
\text { (n, sex, age), recruitment, country }\end{array}$ & $\begin{array}{l}\text { Outcomes } \\
\text { (instruments) }\end{array}$ & $\begin{array}{l}\text { Study } \\
\text { quality* }\end{array}$ & Main findings \\
\hline $\begin{array}{l}\text { Carriedo et } \\
\text { al. (2020) }\end{array}$ & $\begin{array}{l}\text { Cross-sectional study, } 483 \text { elderlies } \\
(50.9 \% \text { women, mean age } \\
65.49 \pm 5.14) \text {, online survey, Spain. }\end{array}$ & $\begin{array}{l}\text { Physical activity } \\
\text { (IPAQ). } \\
\text { Resilience (CD- } \\
\text { RISC). } \\
\text { Affects (The } \\
\text { Positive and } \\
\text { Negative Affect } \\
\text { Schedule). } \\
\\
\text { Depressive } \\
\text { symptoms (six- } \\
\text { item self-report } \\
\text { scale developed } \\
\text { by Kandel and } \\
\text { Davies). }\end{array}$ & 4 & $\begin{array}{l}\text { Older adults } \\
\text { who regularly } \\
\text { engaged in } \\
\text { vigorous } \\
\text { (VPA) and } \\
\text { moderate- } \\
\text { vigorous } \\
\text { physical } \\
\text { activity } \\
\text { (MVPA) } \\
\text { during the } \\
\text { quarantine } \\
\text { reported } \\
\text { higher scores } \\
\text { in resilience } \\
\text { (Locus, Self- } \\
\text { efficacy, and } \\
\text { Optimism), } \\
\text { positive } \\
\text { affect, and } \\
\text { lower in } \\
\text { depressive } \\
\text { symptoms. }\end{array}$ \\
\hline $\begin{array}{l}\text { Suzuki, et } \\
\text { al. (2020) }\end{array}$ & $\begin{array}{l}\text { Longitudinal study, } 165 \text { participants } \\
\text { (69.7\% women, mean age } 78.5 \pm 8.0 \\
\text { years), mailing questionnaire two } \\
\text { moments, one four weeks before the } \\
\text { declaration of the state of } \\
\text { emergency (from } 20 \text { March-15 } \\
\text { April), and the second was in the } \\
\text { four weeks after the declaration of } \\
\text { the state of emergency for follow-up } \\
\text { (from } 16 \text { April to } 13 \text { May), China. }\end{array}$ & $\begin{array}{l}\text { Physical activity } \\
\text { (PAQ-EJ). } \\
\text { Neighbourhood } \\
\text { Physical activity } \\
\text { (IPAQ-E). } \\
\text { Functional } \\
\text { health (TMIG- } \\
\text { IC). } \\
\text { Well-Being } \\
\text { (WHO-5-J). } \\
\text { Health-Related } \\
\text { Quality of Life } \\
\text { (SF-12v2). }\end{array}$ & 5 & $\begin{array}{l}\text { SWB scores } \\
\text { significantly } \\
\text { decreased in } \\
\text { the less active } \\
\text { group but this } \\
\text { was not seen } \\
\text { in the more or } \\
\text { equally active } \\
\text { group. HRQoL } \\
\text { scores were } \\
\text { reduced by } \\
\text { COVID-19 } \\
\text { restrictions } \\
\text { regardless of } \\
\text { changes in } \\
\text { PA. }\end{array}$ \\
\hline
\end{tabular}




\begin{tabular}{|lllll|}
\hline Authors & $\begin{array}{l}\text { Study design, sample characteristics } \\
\text { (n, sex, age), recruitment, country }\end{array}$ & $\begin{array}{l}\text { Outcomes } \\
\text { (instruments) }\end{array}$ & $\begin{array}{l}\text { Study } \\
\text { quality* }\end{array}$ & Main findings \\
\hline
\end{tabular}

Abbreviation: AAS, Active Australia Survey; BAl, Beck Anxiety Inventory; BDI, Beck Depression Inventory; BREQ-3, Behavioural Regulations in Exercise Questionnaire; CES-D, Center for Epidemiological Studies Depression Scales; DASS 21, 21-item Depression, Anxiety and Stress Scale; DASS-9, Depression Anxiety and Stress Scale-9; EPQ, Exercise Participation Questionnaire; EVS, Exercise Vital Sign; GAD-7, General Anxiety Disorder-7; GLQ, Godin Leisure Questionnaire; IPAQ, International Physical Activity Questionnaire; IPAQ-SF, International Physical Activity Questionnaire Short Form; MHC-SF, Mental Health Continuum; NDS, notable depressive symptoms; PA, physical activity; PGWBI, Psychological General Well Being Index; PHQ-9, Patient Health Questionnaire; PSQI, 6items of the Pittsburgh Sleep Quality Index; SAS, Self-Rating Anxiety Scale; SDS, Self-Rating Depression Scale; WEMWBS, Warwick-Edinburgh Mental Wellbeing Scale; WHO-5, 5-World Health Organization Well-Being index; WHOQOL- BREF TR, World Health Organization Quality of Life Scale; VPA, Vigorous Physical Activity; MVPA, Moderate-vigorous Physical Activity; CD-RISC, The ConnorDavidson resilience scale; SWB, Subjective Well-Being; TMIG-IC, Tokyo Metropolitan Institute of Gerontology Index of Competence; IPAQ-E, International Physical Activity Questionnaire Environment Module; PAQ-EJ, Physical Activity Questionnaire for Elderly Japanese; WHO-5-J, World Health Organization's Five Well-being Index; SF-12v2, Medical Outcome Study 12-Item Short-Form Survey v2; SWB, Subjective Well-Being

* According to the Newcastle-Ottawa Scale (NOS) 
Table 2

Characteristics and the main results of the association of physical activity/exercise on mental health among children and adolescents

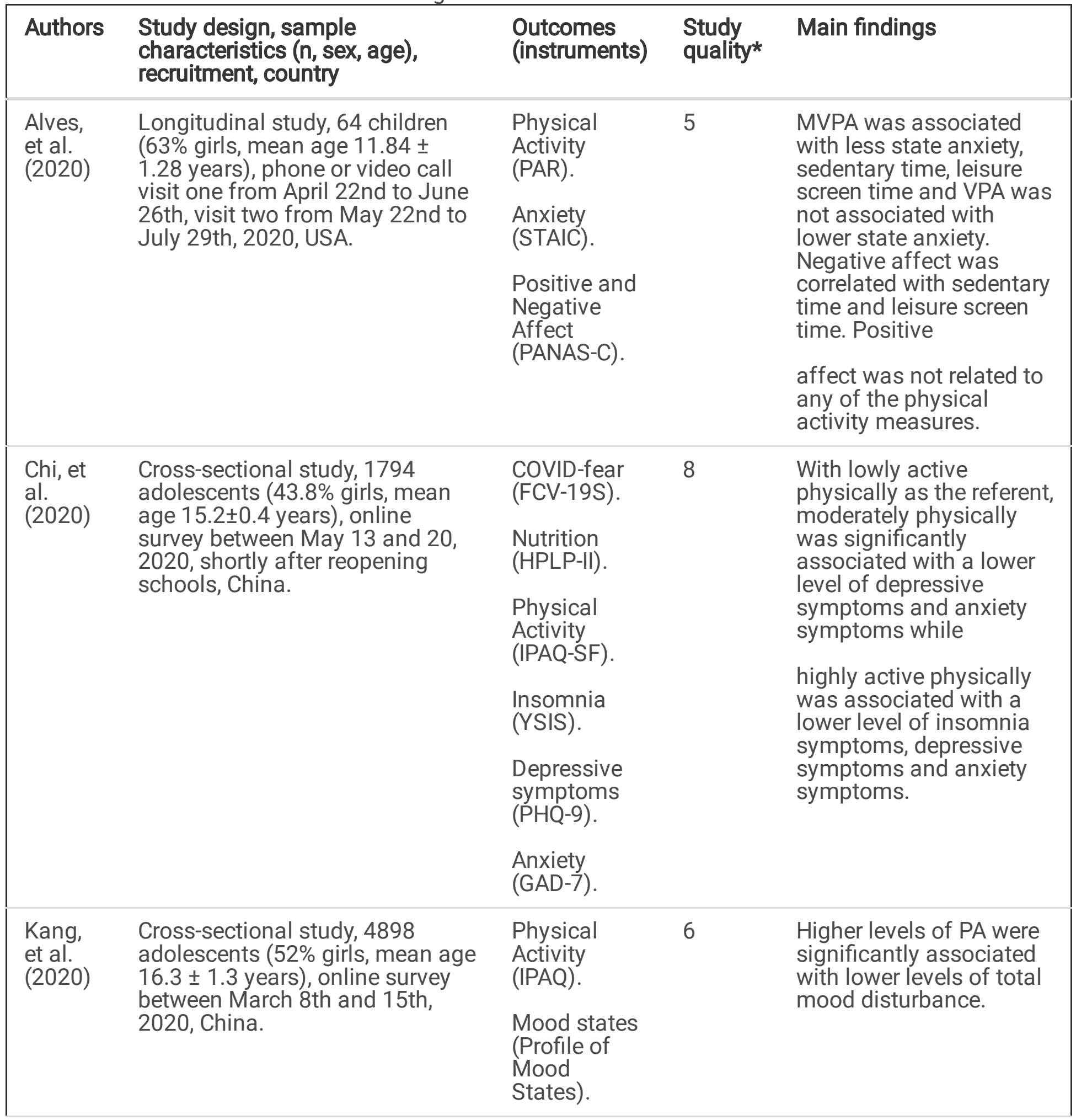




\begin{tabular}{|c|c|c|c|c|}
\hline Authors & $\begin{array}{l}\text { Study design, sample } \\
\text { characteristics ( } \mathrm{n} \text {, sex, age), } \\
\text { recruitment, country }\end{array}$ & $\begin{array}{l}\text { Outcomes } \\
\text { (instruments) }\end{array}$ & $\begin{array}{l}\text { Study } \\
\text { quality* }\end{array}$ & Main findings \\
\hline \multicolumn{5}{|c|}{$\begin{array}{l}\text { Abbreviation: PAR, 24-h physical activity recall; STAIC, State-Trait Anxiety Inventory for Children; } \\
\text { PANAS-C, Positive and Negative Affect Schedule for Children; MVPA, Moderate and vigorous physical } \\
\text { activity; VPA, Vigorous Physical Activity; FCV-19, Chinese version of the Fear of COVID-19 Scale; } \\
\text { (HPLP-II), sub-scale of the Chinese version of the Health Promoting Lifestyle Profile-ll; IPAQ-SF, } \\
\text { International Physical Activity Questionnaire Short Form; YSIS, Youth Self-Rating Insomnia Scales; } \\
\text { PHQ-9, 9-item Patient Health Questionnaire; GAD-7, Generalized Anxiety Disorder scale; PA, Physical } \\
\text { Activity; IPAQ, International Physical Activity Questionnaire. }\end{array}$} \\
\hline \multicolumn{5}{|c|}{ * According to the Newcastle-Ottawa Scale (NOS) } \\
\hline
\end{tabular}

\section{The association between physical activity and mental health among adults and old adults}

The details of the effects of PA on mental health among adults and old adults are summarised in Table 1.

\section{Participants characteristics and date of filling the questionnaires}

The number of participants in the 16 included studies varied between 66 (22) and 8,425 (23) participants. Regarding sex, with exception of two studies $(24,25)$ the majority had more women than men.

Concerning age, most articles presented the mean age range between 20 and 30 years (22, 25-29), one article presented mean age between 30 and 40 years (30); three articles presented mean age between 40 and 50 years $(23,31,32)$; and three articles presented mean age above 50 years (33-35). Three articles did not present mean age $(24,36,37)$, for one the age ranged between 21 and 35 years $(24)$, for another, the age ranged between 21 and 40 years (36), and in one the age ranged between 27 and 53 years (37). In all studies reported, the sample filled out online questionnaires, the time of collecting data varied between studies concerning the stay-at-home order of each country. No article collected data after May. Thirteen studies did cross-sectional analyse and three did a longitudinal analyse.

\section{Study location}

The studies were carried out on five different continents. Five studies from Europe $(29,30,34,36,37)$, four studies from Asia $(22,25,28,35)$, three studies from America $(27,31,32)$ two studies from Africa $(24,26)$, one study from Oceania (33), and one multi-centre study (23).

\section{Outcome and instruments}

Concerning outcomes and instruments, ten articles used the International Physical Activity Questionnaire (IPAQ) to assess PA and one article calculated an estimated cardiorespiratory fitness (algorithm includes age, body composition, resting heart rate and PA) (27). Seven articles assessed PA with different 
instruments $(24,27,29,31-33,38)$. Mental health included analyses of subjective well-being, sleep quality, depressive symptoms, anxiety, quality of life, psychological distress, motivation, resilience, affects (positive and negative) and health-related quality of life.

\section{Main findings}

Overall, all articles found a positive association between PA and better outcomes of mental health (e. g. depression, anxiety, well-being). Articles that observed a decrease in PA during stay-at-home orders order also observed a decrease in well-being (26), negative changes in depression symptoms (small) (27), and negative changes in anxiety and stress symptoms (33). Moreover, it was found that exercise intensity seems to be important. One study found that depression was significantly negatively correlated with METminutes/week in moderate-intensity PA but not vigorous and walking scores (39). Another one found that vigorous PA better predicted depressive symptoms than moderated PA (34). Two studies presented the threshold of PA that should be done to fells the benefits on mental health $(22,37)$. On the other hand, a non-significant association was found between PA and anxiety (31), and between PA and health-related quality of life (35). One study found that the decrease in mental wellbeing and increase in perceived stress was not related to changes in PA (29).

\section{The effects of physical activity on mental health among children and adolescents}

The details of the effects of PA on mental health among children and adolescents are shown in Table 2 .

\section{Participants Characteristics and date of filling the questionnaires}

The number of participants ranged between 64 and 4,898 children and adolescents. More girls than boys participated in the studies. The mean age was 11,15 , and 16 years old. One study that was longitudinal and presents two moments of assessment, also opted for phone or video calls to collect the data (38). The other two were cross-sectional, and collected data by online surveys, one on March and another in May $(40,41)$.

\section{Study location}

One study was from the USA (38) and the other two were from China $(40,41)$.

\section{Outcome and instruments}

Two studies assessed PA by the International physical activity questionnaire (IPAQ) questionnaire (40, 41), and another one used a 24-h physical activity recall (38). Regarding mental health, different outcomes were assessed such as anxiety, positive and negative affect, insomnia, depressive symptoms, and mood states.

\section{Main findings}


Moderate PA was associated with less state anxiety $(38,40)$. Positive affect was not related to physical activity (38). Higher levels of PA were also significantly associated with lower levels of total mood disturbance (41).

\section{Discussion}

This systematic review focuses on the effects of PA on mental health during the COVID-19 pandemic. In particular, we sought to answer if PA is associated with mental health during the COVID-19 pandemic and if PA mitigates the effects of the stay-at-home order on mental health. The COVID-19 pandemic generated numerous challenges for public health, particularly the significant burden of mental health in the population $(42,43)$. In addition, PA has been recognized as an effective mitigation strategy for improving mental health (44). The COVID-19 pandemic has been affected all continents in the world, at different scales. This study analysed 19 research works, 16 about adults and old adults and 3 about children and adolescents. The articles are mainly cross-sectional studies and four are longitudinal studies. In nearly all of the studies that comprised the present systematic review sample, investigators used online surveys as the main procedure to collect data. Overall, the studies suggested that higher PA is associated with less negative mental health symptoms, such as depression, anxiety, and fear, independently of age.

The studies observed that women showed more depressive symptoms than men $(22,37,40,41)$. Furthermore, individuals with a lower level of masculinity traits (not specifically females) increased risk of developing depression (28), and women experienced more generalised anxiety (32). The reduction of PA levels may mostly influence the mental well-being of the female (36). Those findings are expected since the literature is consistent in signalising the sex differences in most mental disorders (45). On the whole, the prevalence rates of anxiety and depression were both higher than the rates found in previous studies before the COVID-19 pandemic $(25,27,28,30,33)$, which highlights a worsening in mental health postCOVID-19 pandemic.

Four articles did a longitudinal study, three with adults and old adults $(22,29,35)$ and one with children (38). Among the studies that have collected measures before and after the stay-at-home order, both observed a significant reduction in PA $(29,35)$. Other studies also reported a reduction in self-reported PA $(26,27,30,33,36)$. The reduction was more pronounced in men than women $(23,29,36)$, in vigorous PA (36), and between those with lower health-related quality of life scores before the COVID-19 pandemic (35). The possible explanation for sex-difference is that men are more engaged in group/community PA and sports at clubs or gyms, and those were more impacted by the COVID-19 restriction. Also, women are more engaged in low and moderate physical activities, which can be done at home, besides, women spent more time in housework activities. Women without changes in childcare provision reported more opportunities to be physically active (32). The same sex-differences were observed in an Italian study (46). Increases in PA were observed for a minority, but it was interesting that the majority of the respective study samples that exhibited a positive change were individuals who did not meet recommended PA guidelines before the COVID-19 pandemic $(23,36)$. Additional reasons could be an increase in awareness for health issues and more time to pursue PA during the stay-at-home order (23). This can help maintain 
a more active lifestyle during and after the pandemic. Another study found an increase of $40 \%$ in PA in a sample that was already active before the COVID-19 pandemic (31). PA could be used as a coping strategy to deal with the consequences of the pandemic. The place that individuals prefer to practice PA seems to be important, since active participants reported greater connectedness to nature and nature relatedness than the inactive population (31).

There was no consensus across studies for the optimal PA levels for mitigating negative mental symptoms. Among Chinese students, 2500 METs minute/week of PA every week was the optimal load to alleviate negative emotion (22). On the other hand, a Spanish community sample study showed that 477 METs-minute/week was associated with a $33 \%$ decrease in the probabilities of notable depressive symptoms (37). The difference between the values must be relativised considering the samples' characteristics. The first one is students with a mean age of 20 years (22), and the second one is a community sample with a mean age of 43.2 years for women and 40.5 years for men (37). In addition, it is claimed that at least 3000 METs-minute/week reduce the odds of depressive symptoms by 47\% (37). These studies used the IPAQ to assess PA, and according to IPAQ, to reach a minimally active category at least 600 METs minute/week is needed (47). The American College of Sports Medicine also recommends for healthy adults aged 18-65 years at least 600 METs minute/week but did not specify the minimum dose to prevent depressive symptoms $(12,48)$.

Studies also examined the association of PA and mental health according to PA intensity. Moderateintensity PA (e.g., walking or jogging on a treadmill, using an elliptical trainer, cleaning house) is associated with better mental health outcomes than vigorous-intensity PA (28). On the other hand, vigorous-intensity PA better predicted depressive symptoms than moderate-intensity PA; also the effect size was higher for the association between vigorous-intensity PA and level of resilience compared with moderate-intensity PA (34). One study found that performing high PA levels has no positive effect on depressive symptoms (37). Another study explored the type of PA and showed that stretching and resistance training were associated with lower anxiety, and three types of PA (household chores, stretching, and resistance training) were associated with lower depression symptoms (25).

Sedentary behaviour was observed in few studies and contradictory findings were observed. No association between sedentary time and depressive symptoms was observed (28). However, other studies have shown that sedentary behaviour was associated with poorer mental health and well-being (23) and perceived stress (29).

Concerning the association of PA and mental health outcomes among children and adolescents, only three articles were selected. Some issues must be highlighted. This population had to face, beyond the reality changed from the COVID-19 pandemic, the changes in the education system as online learning became the main learning method for students and uncertainty of academic development, which probably caused more anxiety level $(38,40)$. Both moderate and highly active groups were significantly associated with less depressive symptoms $(40)$ and anxiety $(38,40)$, and only the most active adolescents reported significantly lower insomnia symptoms (40) and better mood states (41). 
Regarding old-age samples, the studies mentioned the particular vulnerability to changes in social circumstances, and highlight the importance of health-related quality of life (35) and levels of resilience (34) to deal with the consequences of the COVID-19 pandemic on the PA level.

The present systematic review had some limitations that must be mentioned. First, the studies present correlative analyses, not causal ones, thus randomised controlled trials must be conducted in the context of the COVID-19 pandemic and the stay-at-home orders to clarify the direction of the association. However, beyond the COVID-19 context, randomised controlled trials showed that PA interventions show beneficial effects for mental health outcomes such as depression and anxiety (49). Thus, a nuanced perspective particularly during the COVID-19 context in future research is needed. Moreover, the included studies with community samples were limited, and the analyses were mostly based on convenience samples with college students, which had specific characteristics and low mean age. Thus, future research needs to focus on representative study samples.

\section{Conclusion}

This review helps to clarify the positive association of PA and mental health during the COVID-19 pandemic, especially considering the effects of the stay-at-home order worldwide. Although there is an association between increased PA and improved mental health, further studies are needed, specifically randomised clinical trials, to identify the direction of this relationship, and what kind of PA, intensity, and frequency are most indicated to maximise the effects. The impact of the COVID-19 pandemic on mental health may be continuous and long-term $(50,51)$, thus, public health agencies must provide timely and effective interventions, where PA and exercise should be a priority.

\section{List Of Abbreviations}

COVID-19, Coronavirus disease-19.

SARS-CoV-2, Severe acute respiratory syndrome coronavirus-2

PA, Physical activity

WHO, World Health Organization

IPAQ, International physical activity questionnaire

MET, metabolic equivalent

\section{Declarations}

\section{Ethics approval and consent to participate}

Not applicable. 


\section{Consent for publication}

Not applicable.

\section{Availability of data and materials}

Data sharing is not applicable to this article as no datasets were generated or analysed during the current study.

\section{Competing interests}

The authors declare that they have no competing interests.

\section{Authors' contributions}

All authors were involved in drafting the article or revising it critically for important intellectual content, and all authors approved the final version to be submitted for publication. PM, MP and AM had full access to all of the data in the study and takes responsibility for the integrity of the data and the accuracy of the data analysis. PM, MP and AM, study conception and design. PM and MP acquisition of data. PM, MP and AM, analysis and interpretation of data.

\section{Funding}

No funding.

\section{Acknowledgements}

Al acknowledges support from the Swiss National Centre of Competence in Research LIVES Overcoming vulnerability: life course perspectives, granted by the Swiss National Science Foundation (grant number: 51NF40-185901). Al acknowledges support from the Swiss National Science Foundation (grant number: 10001C_189407). André Werneck is supported by the São Paulo Research Foundation (FAPESP) with a PhD scholarship (FAPESP process: 2019/24124-7). This paper presents an independent research. The views expressed in this publication are those of the authors and not necessarily those of the acknowledged institutions.

\section{References}

1. Conti P, Caraffa A, Gallenga CE, Kritas SK, Frydas I, Younes A, et al. The British variant of the new coronavirus-19 (Sars-Cov-2) should not create a vaccine problem. J Biol Regul Homeost Agents. 2020;35(1).

2. Ritchie HO-O, E.; Beltekian, D.; Mathieu, E.; Hasell, J.;Macdonald, B.; Giattino, C. and Roser; M. Coronavirus (COVID-19) Vaccinations 2021 [Available from: https://ourworldindata.org/covidvaccinations. 
3. Organization WH. Coronavirus disease (COVID-19): Vaccines 2021 [Available from: https://www.who.int/news-room/q-a-detail/coronavirus-disease-(covid-19)-vaccines? adgroupsurvey $=\{$ adgroupsurvey $\} \& g c l i d=C j w K C A i A 1$ eKBBhBZEiwAX3gqlwcwqCmOIN-6welx1MsuxpyYUyvsWAV-BYZOJ1g1qS0oUYbLEPiZxoC9uQQAvD_BwE.

4. Organization WH. WHO Coronavirus Disease (COVID-19) Dashboard 2021 [Available from: https://covid19. who.int/?gclid=CjwKCAiAmrOBBhA0EiwArn3mfDVdryFCBj-_IYP99HuMasLYQzoVDYdfWMBkTmfFA8QVtmSOncCTRoCiFIQAvD_BwE.

5. European Centre for Disease Prevention and Control. Data on country response measures to COVID192021 [Available from: https://www.ecdc.europa.eu/en/publications-data/download-dataresponse-measures-covid-19.

6. Moreland A, Herlihy C, Tynan MA, Sunshine G, McCord RF, Hilton C, et al. Timing of state and territorial COVID-19 stay-at-home orders and changes in population movement-United States, March 1-May 31, 2020. Morbidity and Mortality Weekly Report. 2020;69(35):1198.

7. Valentin F, Sylvain I, Oulmann Z, Rachel FR, Joël B, Pierre-Michel L, et al. COVID-19 pandemic lockdown and problematic eating behaviors in a student population. Journal of Behavioral Addictions JBA. 2020;9(3):826-35.

8. Chodkiewicz J, Talarowska M, Miniszewska J, Nawrocka N, Bilinski P. Alcohol Consumption Reported during the COVID-19 Pandemic: The Initial Stage. International journal of environmental research and public health. 2020;17(13):4677.

9. Wei Y, Shah R. Substance Use Disorder in the COVID-19 Pandemic: A Systematic Review of Vulnerabilities and Complications. Pharmaceuticals. 2020;13(7):155.

10. Salari N, Hosseinian-Far A, Jalali R, Vaisi-Raygani A, Rasoulpoor S, Mohammadi M, et al. Prevalence of stress, anxiety, depression among the general population during the COVID-19 pandemic: a systematic review and meta-analysis. Globalization and health. 2020;16(1):57.

11. Chen Q, Li M, Wang Y, Zhang L, Tan X. Changes in anxiety, depression, and stress in one week and one month later after the Wuhan shutdown against the COVID-19 epidemic. Disaster Medicine and Public Health Preparedness. 2021:1-32.

12. Teychenne M, White RL, Richards J, Schuch FB, Rosenbaum S, Bennie JA. Do we need physical activity guidelines for mental health: What does the evidence tell us? Mental health and physical activity. 2020;18:100315.

13. Marques A, Peralta M, Martins J, Catunda R, Matos MG, Saboga Nunes L. Associations between physical activity and self-rated wellbeing in European adults: A population-based, cross-sectional study. Prev Med. 2016;91:18-23.

14. WHO. Physical Inactivity: a global public health problem 2021 [Available from: https://www.who.int/ncds/prevention/physical-activity/inactivity-global-health-problem/en/.

15. Marques A, Henriques-Neto D, Peralta M, Martins J, Demetriou Y, Schonbach DMI, et al. Prevalence of Physical Activity among Adolescents from 105 Low, Middle, and High-income Countries. Int J Environ Res Public Health. 2020;17(9). 
16. Guthold R, Stevens GA, Riley LM, Bull FC. Worldwide trends in insufficient physical activity from 2001 to 2016: a pooled analysis of 358 population-based surveys with 1.9 million participants. The Lancet Global health. 2018;6(10):e1077-e86.

17. Stockwell S, Trott M, Tully M, Shin J, Barnett Y, Butler L, et al. Changes in physical activity and sedentary behaviours from before to during the COVID-19 pandemic lockdown: a systematic review. BMJ Open Sport \&amp;amp; Exercise Medicine. 2021;7(1):e000960.

18. Violant-Holz V, Gallego-Jiménez MG, González-González CS, Muñoz-Violant S, Rodríguez MJ, Sansano-Nadal O, et al. Psychological Health and Physical Activity Levels during the COVID-19 Pandemic: A Systematic Review. Int J Environ Res Public Health. 2020;17(24).

19. Wells GA, Shea B, O'Connell Da, Peterson J, Welch V, Losos M, et al. The Newcastle-Ottawa Scale (NOS) for assessing the quality of nonrandomised studies in meta-analyses. Oxford; 2000.

20. Modesti PA, Reboldi G, Cappuccio FP, Agyemang C, Remuzzi G, Rapi S, et al. Panethnic Differences in Blood Pressure in Europe: A Systematic Review and Meta-Analysis. PloS one. 2016;11(1):e0147601.

21. Moher D, Liberati A, Tetzlaff J, Altman DG. Preferred reporting items for systematic reviews and meta-analyses: the PRISMA statement. BMJ. 2009;339:b2535.

22. Zhang Y, Zhang H, Ma X, Di Q. Mental Health Problems during the COVID-19 Pandemics and the Mitigation Effects of Exercise: A Longitudinal Study of College Students in China. International journal of environmental research and public health. 2020;17(10).

23. Faulkner J, O'Brien WJ, McGrane B, Wadsworth D, Batten J, Askew CD, et al. Physical activity, mental health and well-being of adults during initial COVID-19 containment strategies: A multi-country crosssectional analysis. Journal of science and medicine in sport. 2020.

24. Eric NO, Oghenebrorien AE, Onogimesike AT, Suoke OP. Mental wellbeing and exercise participation during covid-19 pandemic among adult residents of Nigeria's niger delta. International Journal of Human Movement and Sports Sciences. 2020;8(6):534-42.

25. Xiang MQ, Tan XM, Sun J, Yang HY, Zhao XP, Liu L, et al. Relationship of Physical Activity With Anxiety and Depression Symptoms in Chinese College Students During the COVID-19 Outbreak. Frontiers in psychology. 2020;11:582436.

26. Chouchou F, Augustini M, Caderby T, Caron N, Turpin NA, Dalleau G. The importance of sleep and physical activity on well-being during COVID-19 lockdown: reunion island as a case study. Sleep medicine. 2020.

27. Coughenour C, Gakh M, Pharr JR, Bungum T, Jalene S. Changes in Depression and Physical Activity Among College Students on a Diverse Campus After a COVID-19 Stay-at-Home Order. Journal of community health. 2020:1-9.

28. Lin J, Guo T, Becker B, Yu Q, Chen ST, Brendon S, et al. Depression is Associated with ModerateIntensity Physical Activity Among College Students During the COVID-19 Pandemic: Differs by Activity Level, Gender and Gender Role. Psychology research and behavior management. 2020;13:1123-34. 
29. Savage MJ, James R, Magistro D, Donaldson J, Healy LC, Nevill M, et al. Mental health and movement behaviour during the COVID-19 pandemic in UK university students: Prospective cohort study. Mental health and physical activity. 2020;19.

30. Ozdemir F, Cansel N, Kizilay F, Guldogan E, Ucuz I, Sinanoglu B, et al. The role of physical activity on mental health and quality of life during COVID-19 outbreak: A cross-sectional study. European journal of integrative medicine. 2020;40:101248.

31. Lesser IA, Nienhuis CP. The Impact of COVID-19 on Physical Activity Behavior and Well-Being of Canadians. International journal of environmental research and public health. 2020;17(11).

32. Nienhuis CP, Lesser IA. The Impact of COVID-19 on Women's Physical Activity Behavior and Mental Well-Being. International journal of environmental research and public health. 2020;17(23).

33. Stanton R, To QG, Khalesi S, Williams SL, Alley SJ, Thwaite TL, et al. Depression, Anxiety and Stress during COVID-19: Associations with Changes in Physical Activity, Sleep, Tobacco and Alcohol Use in Australian Adults. International journal of environmental research and public health. 2020;17(11).

34. Carriedo A, Cecchini JA, Fernandez-Rio J, Méndez-Giménez A. COVID-19, Psychological Well-being and Physical Activity Levels in Older Adults During the Nationwide Lockdown in Spain. The American journal of geriatric psychiatry : official journal of the American Association for Geriatric Psychiatry. 2020;28(11):1146-55.

35. Suzuki Y, Maeda N, Hirado D, Shirakawa T, Urabe Y. Physical Activity Changes and Its Risk Factors among Community-Dwelling Japanese Older Adults during the COVID-19 Epidemic: Associations with Subjective Well-Being and Health-Related Quality of Life. International journal of environmental research and public health. 2020;17(18).

36. Maugeri G, Castrogiovanni P, Battaglia G, Pippi R, D'Agata V, Palma A, et al. The impact of physical activity on psychological health during Covid-19 pandemic in Italy. Heliyon. 2020;6(6):e04315.

37. Méndez-Giménez A, Cecchini JA, Fernández-Río J, Carriedo A. Physical Activity and Prevention of Depressive Symptoms in the Spanish Population during Confinement due to COVID-19. Psicothema. 2021;33(1):111-7.

38. Alves JM, Yunker AG, DeFendis A, Xiang AH, Page KA. Associations between Affect, Physical Activity, and Anxiety Among US Children During COVID-19. medRxiv : the preprint server for health sciences. 2020.

39. Lin JY, Guo TY, Becker B, Yu Q, Chen ST, Brendon S, et al. Depression is Associated with ModerateIntensity Physical Activity Among College Students During the COVID-19 Pandemic: Differs by Activity Level, Gender and Gender Role. Psychology research and behavior management. 2020;13:1123-34.

40. Chi X, Liang K, Chen ST, Huang Q, Huang L, Yu Q, et al. Mental health problems among Chinese adolescents during the COVID-19: The importance of nutrition and physical activity. International journal of clinical and health psychology : IJCHP. 2020:100218.

41. Kang S, Sun Y, Zhang X, Sun F, Wang B, Zhu W. Is Physical Activity Associated with Mental Health among Chinese Adolescents during Isolation in COVID-19 Pandemic? Journal of epidemiology and 
global health. 2020.

42. Lima CKT, Carvalho PMM, Lima I, Nunes J, Saraiva JS, de Souza RI, et al. The emotional impact of Coronavirus 2019-nCoV (new Coronavirus disease). Psychiatry research. 2020;287:112915.

43. Hahad O, Gilan DA, Daiber A, Münzel T. [Public Mental Health as One of the Key Factors in Dealing with COVID-19]. Gesundheitswesen. 2020;82(5):389-91.

44. Jakobsson J, Malm C, Furberg M, Ekelund U, Svensson M. Physical Activity During the Coronavirus (COVID-19) Pandemic: Prevention of a Decline in Metabolic and Immunological Functions. Frontiers in Sports and Active Living. 2020;2(57).

45. Riecher-Rössler A. Sex and gender differences in mental disorders. The Lancet Psychiatry. 2017;4(1):8-9.

46. Giustino V, Parroco AM, Gennaro A, Musumeci G, Palma A, Battaglia G. Physical Activity Levels and Related Energy Expenditure during COVID-19 Quarantine among the Sicilian Active Population: A Cross-Sectional Online Survey Study. Sustainability. 2020;12(11).

47. Committee IR. Guidelines for data processing and analysis of the International Physical Activity Questionnaire (IPAQ)-short and long forms. http://www ipaq ki se/scoring pdf. 2005.

48. Thompson PD, Arena R, Riebe D, Pescatello LS. ACSM's new preparticipation health screening recommendations from ACSM's guidelines for exercise testing and prescription. Current sports medicine reports. 2013;12(4):215-7.

49. Neill RD, Lloyd K, Best P, Tully MA. The effects of interventions with physical activity components on adolescent mental health: Systematic review and meta-analysis. Mental health and physical activity. 2020;19:100359.

50. Gan Y, Ma J, Wu J, Chen Y, Zhu H, Hall BJ. Immediate and delayed psychological effects of provincewide lockdown and personal quarantine during the COVID-19 outbreak in China. Psychological Medicine. 2020:1-12.

51. Sher L. The impact of the COVID-19 pandemic on suicide rates. QJM : monthly journal of the Association of Physicians. 2020;113(10):707-12.

\section{Figures}




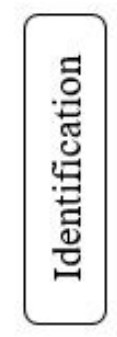

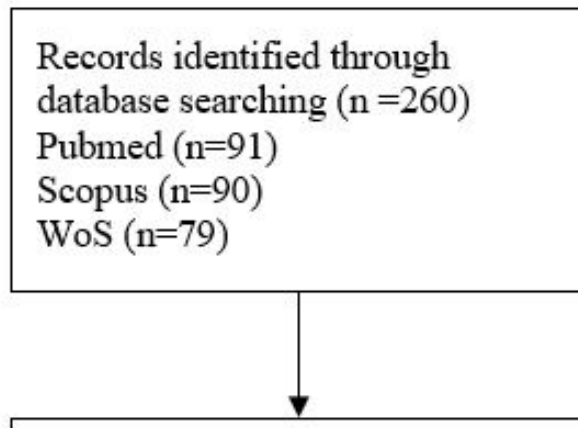

Records after duplicates removed $(\mathrm{n}=113)$

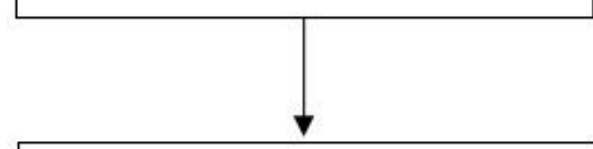

\section{Records screened} $(\mathrm{n}=113)$

Records excluded $(\mathrm{n}=56)$

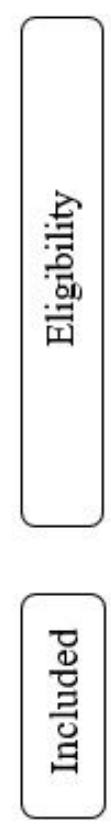

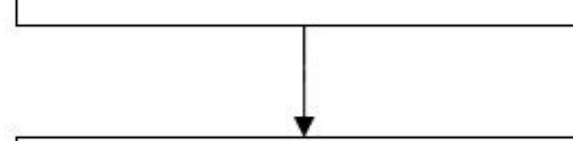

Full-text articles assessed for eligibility

$(\mathrm{n}=57)$

\begin{tabular}{|l|}
\hline $\begin{array}{l}\text { Studies included in qualitative } \\
\text { synthesis } \\
(\mathrm{n}=19)\end{array}$ \\
\hline $\begin{array}{l}\text { Studies included in the study } \\
(\mathrm{n}=19)\end{array}$ \\
\hline
\end{tabular}

Full-text articles excluded, with reasons

$(\mathrm{n}=38)$

\section{Figure 1}

Flow diagram of study selection 